\title{
KANDUNGAN KARBON ORGANIK TOTAL DAN FOSFAT PADA SEDIMEN DI PERAIRAN MUARA SUNGAI BANYUASIN, SUMATERA SELATAN
}

\section{TOTAL ORGANIC CARBON CONTENT AND PHOSPHATE IN SEDIMENTS AT THE BANYUASIN RIVER ESTUARY, SOUTH SUMATERA}

\author{
Beta Susanto Barus*, Roy Yosua Munthe, \& Miko Bernando \\ Jurusan Ilmu Kelautan, FMIPA, Universitas Sriwijaya, Ogan Ilir, 30662, Indonesia \\ *E-mail: betasusanto@unsri.ac.id
}

\begin{abstract}
Anthropogenic activity produces domestic and agricultural wastes that are distributed to the waters which can affect the high and low levels of total organic carbon and phosphate from these waters. The purpose of this research was to analyze the total organic carbon content and phosphate and analyze the distribution and the correlation of total organic carbon and phosphate in sediments of the Banyuasin Estuary, South Sumatra. This research was conducted in November 2019. Sampling of sediments using purposive method at 10 stations during low tide. Analysis of total organic carbon using Ash Content method according to SNI 01-2891-1992, and phosphate analysis using the Bray and Kurtz method. Distribution patterns of total organic carbon concentration and phosphate were analyzed using Surfer 9. Correlation analysis was conducted with Ms. Excel. The results showed that the total organic carbon concentration ranged from 3.71-7.42\% and the phosphate concentration ranged from $16.49 \mathrm{mg} / \mathrm{kg}-26.45 \mathrm{mg} / \mathrm{kg}$. The distribution of total organic carbon and phosphate is influenced by the type of sediment substrate at each station. Smoother sediments have higher total organic matter and phosphate content. Total organic carbon and phosphate in the Banyuasin Estuary waters have a positive and strong correlation which indicates that the higher the total organic carbon content in the waters, the higher the phosphate content.
\end{abstract}

Keywords: Banyuasin estuary, phosphate, sediments, total organic carbon

\begin{abstract}
ABSTRAK
Aktivitas antropogenik menghasilkan limbah domestik dan pertanian yang terdistribusi ke perairan yang dapat memengaruhi tinggi rendahnya kandungan karbon organik total dan fosfat dari perairan. Tujuan dari penelitian ini adalah untuk menganalisis kandungan karbon organik total dan fosfat serta menganalisis sebaran dan korelasi konsentrasi karbon organik total dan fosfat pada sedimen dasar di muara Sungai Banyuasin, Sumatera Selatan. Penelitian ini dilaksanakan pada bulan November 2019. Pengambilan sampel sedimen menggunakan metode purposive sampling pada 10 stasiun saat kondisi surut. Analisis karbon organik total menggunakan metode Kadar Abu sesuai dengan SNI 01-28911992 dan analisis fosfat dengan metode Bray and Kurtz. Pola sebaran konsentrasi karbon organik total dan fosfat dianalisis menggunakan software Surfer 9. Analisis korelasi dilakukan dengan program $M s$. Excel. Hasil penelitian menunjukkan bahwa konsentrasi karbon organik total berkisar antara 3,71$7,42 \%$ dan konsentrasi fosfat berkisar antara $16,49 \mathrm{mg} / \mathrm{kg}-26,45 \mathrm{mg} / \mathrm{kg}$. Sebaran konsentrasi karbon organik total dan fosfat dipengaruhi oleh tipe substrat sedimen pada setiap stasiun. Sedimen dengan tekstur yang lebih halus memiliki kandungan bahan organik total dan fosfat lebih tinggi. Karbon organik total dan fosfat di perairan muara Sungai Banyuasin memiliki korelasi yang positif dan kuat. Semakin tinggi kandungan karbon organik total di perairan akan diikuti dengan semakin tinggi juga kandungan fosfatnya.
\end{abstract}

Kata kunci: fosfat, karbon organik total, Muara Sungai Banyuasin, sedimen 


\section{PENDAHULUAN}

Karbon organik merupakan salah satu komponen penting bagi kehidupan biota laut. Kandungan karbon organik mudah urai di perairan dapat menyumbang kesuburan dan kualitas perairan. Karbon organik berasal dari 2 (dua) sumber yaitu alamiah dan aktivitas antropogenik. Beberapa bahan organik dapat terdekomposisi dan diubah menjadi komponen anorganik, namun sebagian tidak dapat berubah dan menjadi komponen penting sebagai penyusun unsur kimiawi di sedimen dan dapat menyerap senyawa kimiawi lain yang terlarut dalam air.

Fosfat mempunyai peranan penting sebagai zat hara yang diperlukan untuk kehidupan organisme di laut (Patty et al., 2015). Selain bersumber dari pelapukan batuan mineral dari daratan, fosfat di perairan juga dapat berasal dari degradasi bahan organik sehingga jika kandungan karbon organik di suatu perairan memiliki konsenstrasi yang tinggi maka terdapat kemungkinan kandungan fosfat di perairan tersebut juga tinggi.

Sedimen berfungsi sebagai tempat terakumulasinya berbagai bahan kimia di perairan termasuk bahan organik dan fosfat. Hal tersebut menyebabkan konsentrasi fosfat dan karbon organik di sedimen lebih tinggi dibandingkan di kolom perairan (Muchtar, 2012). Karbon organik mudah terakumulasi ke dalam partikel lebih halus seperti lanau dan lempung (Latifah et al., 2013). Selain itu, ekspor dan akumulasi kandungan organik di sedimen laut sangat bervariasi dari satu tempat ke tempat lain (François et al., 2002). Endapan fosfor $(\mathrm{P})$ dan karbon organik yang telah terdegradasi dapat terlepas kembali dari sedimen ke perairan. Senyawa fosfor (P) yang terakumulasi di sedimen mengalami proses dekomposisi dengan proses biotik yaitu dengan bantuan bakteri maupun melalui proses abiotik yang menghasilkan senyawa fosfat terlarut yang dapat kembali ke dalam kolom air melalui difusi (Seitzinger et al., 2005). Kesuburan lingkungan perairan sangat dipengaruhi oleh pelepasan endapan fosfor
(P) dan karbon organik karena berfungsi sebagai regenerator nutrien di kolom perairan. Sumber fosfat terbesar di perairan berasal dari sedimen (Schlesinger \& Bernhardt, 2013).

Muara Sungai Banyuasin merupakan perairan dengan tingkat sedimentasi yang tinggi. Hartoni \& Agussalim (2007) melaporkan tingkat sedimentasi di muara Sungai Banyuasin dengan laju 0,1968-3,1872 $\mathrm{kg} / \mathrm{m}^{2} /$ hari. Daerah muara Sungai Banyuasin juga merupakan daerah aliran pembuangan limbah industri, domestik serta adanya aktivitas manusia di sekitarnya. Material terlarut dan tersuspensi yang mesuk ke perairan dapat memberikan pengaruh terhadap penurunan kualitas perairan seperti perubahan sifat kimia dan fisika perairan (Barus et al., 2019). Bahan organik yang terakumulasi di sedimen semakin meningkat dalam kurun waktu yang lama seiring dengan semakin banyaknya aktivitas manusia. Beberapa penelitian telah dilakukan mengenai konsentrasi fosfat di sedimen pada Muara Sungai Banyuasin (Permatasari et al., 2019; Putri et al., 2019), namun sangat sedikit yang meneliti tentang kandungan organik total dan hubungannya dengan fosfat di sedimen. Penelitian ini bertujuan untuk menganalisi kandungan karbon organik total dan fosfat serta menganalisi sebaran dan korelasi karbon organik total dan fosfat pada sedimen di muara Sungai Banyuasin, Sumatra Selatan.

\section{METODE PENELITIAN}

Penelitian ini dilaksanakan pada bulan November 2019 di Perairan Sungai Banyuasin Sumatera Selatan. Metode pengambilan sampel adalah metode purposive sampling. Stasiun 1, 2, dan 3 mewakili muara sungai bagian dalam yang merupakan titik pertemuan dua aliran sungai yaitu Sungai Banyuasin dan Sungai Lalan. Stasiun 4, 5, 6 dan 7 mewakili muara sungai bagian tengah yang merupakan daerah yang terdapat aktivitas pelabuhan Tanjung Api-api, dan stasiun 8, 9, dan 10 mewakili bagian luar 
muara sungai yang lebih banyak dipengaruhi oleh laut. Pengambilan sampel sedimen dilakukan saat kondisi surut pada 10 stasiun (Figure 1).

Sampel sedimen diambil secara komposit dengan 3 kali pengulangan menggunakan ekman grab dan dianalisis di laboratorium. Hasil analisis ketiga sampel kemudian dicari nilai rata-ratanya sebagai angka konsentrasi yang digunakan. Sampel sedimen yang diambil adalah sedimen permukaan dengan ketebalan $3 \mathrm{~cm}$. Metode yang digunakan dalam analisis karbon organik total adalah metode Kadar Abu sesuai dengan SNI 01-2891-1992. Kandungan karbon organik total sedimen dihitung dengan persamaan sebagai berikut (Allen \& Hajek, 1976):

$$
L i=\frac{W_{0} W_{t}}{W_{0}} \times 100 \%
$$

Keterangan: $\mathrm{Li}=$ loss on ignation $(\%) ; \mathrm{Wo}=$ berat awal; $\mathrm{Wt}=$ berat akhir.

Analisis fosfat dengan metode Bray \& Kurtz (1945). Sampel sedimen yang digunakan dalam analisis karbon organik total dan fosfat adalah sedimen yang sama dengan analisis fraksi sedimen, yaitu sedimen yang terambil langsung dari dasar perairan. Analisis fraksi sedimen adalah pengayakan basah dengan sieve shaker dan dilanjutkan pemipetan (Rifardi, 2008). Penentuan tekstur sedimen menggunakan segitiga Shepard. Fraksi sedimen dibutuhkan untuk melihat jenis substrat yang ada pada lokasi penelitian. Hal tersebut akan dibahas secara deskriptif kaitannya dengan kandungan total organik karbon dan fosfat di sedimen tersebut. Hasil yang diperoleh dari pengukuran dan perhitungan fraksi sedimen, konsentrasi fosfat dan karbon organik total pada sedimen diolah dengan menggunakan perangkat lunak Ms. Excel yang kemudian akan ditampilkan dalam bentuk tabel dan grafik serta dianalisis korelasinya. Selanjut-

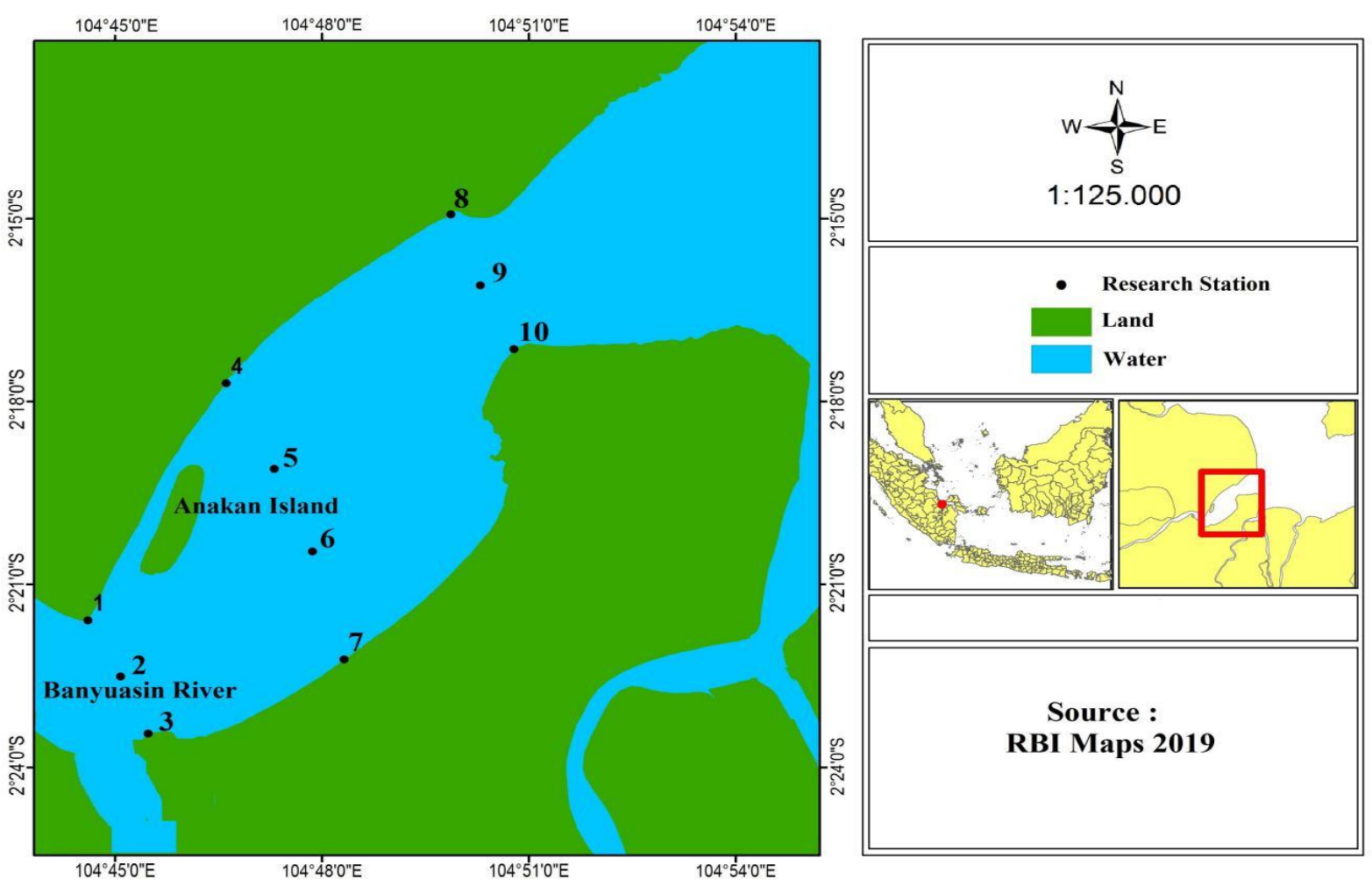

Figure 1. Research Location. 
nya nilai kandungan fosfat sedimen akan diklasifikasikan berdasarkan Hakanson \& Bryann (2008) yang menyatakan tentang penggolongan kesuburan perairan dengan nilai kisarn berikut: kandungan fosfat 0,000 $0,020 \mathrm{mg} / \mathrm{l}$ tergolong pada kesuburan rendah (oligotrofik); 0,021-0,050 mg/l tergolong kesuburan sedang (mesotrofik); 0,051-0,100 $\mathrm{mg} / \mathrm{l}$ tergolong kesuburan tinggi (eutrofik), dan perairan dengan kisaran $>0,100 \mathrm{mg} / \mathrm{l}$ tergolong kesuburan yang sangat tinggi (hypertrofik). Pola sebaran konsentrasi karbon organik total dan fosfat dianalisis menggunakan software Surfer 9. Analisis korelasi antara konsentrasi kandungan karbon organik total dan konsentrasi fosfat di sedimen diolah dengan Ms. Excel dan dibahas secara deskriptif.

\section{HASIL DAN PEMBAHASAN}

\subsection{Jenis Fraksi Sedimen}

Sedimen merupakan tempat terakumulasinya zat-zat yang terdapat diperairan seperti bahan organik. Bahan organik yang terdapat di kolom perairan akan mengendap di sedimen dasar perairan. Analisi fraksi sedimen dengan segitiga Shephard menunjukkan bahwa perairan Muara Sungai Banyuasin memiliki fraksi sedimen yang sangat bervariasi. Stasiun 2, 5, 7, 8, dan 9 dominan ditemukan sedimen bertekstur lempung. Stasiun 3 dan 10 dominan ditemu- kan sedimen dengan tekstur lempung berpasir, Stasiun 4 dan 6 ditemukan jenis pasir berlanau dan stasiun 1 berjenis sedimen pasir berlempung. Secara umum, tipe substrat pada muara Sungai Banyuasin yang mengarah lebih ke laut memilik tekstur yang lebih halus. Pola arus di muara Sungai Banyuasin sangat memengaruhi pergerakan sedimen dimana semakin menuju ke arah laut kecepatan arusnya semakin lemah sehingga memudahkan partikel yang lebih halus untuk mengendap (Simbolon et al., 2015). Sanusi \& Putranto (2009) mengatakan bahwa konsentrasi bahan organik di sedimen sangat dipengaruhi oleh tekstur dari sedimen itu sendiri. Sedimen dengan tekstur yang lebih halus memiliki kemampuan menyerap bahan organik lebih tinggi dibandingkan dengan tekstur yang kasar/besar. Sedimen yang memiliki tekstur halus biasanya berada pada perairan yang relatif tenang seperti hilir dan estuari, sedangkan untuk tekstur sedimen kasar biasanya berada pada daerah yang memiliki kondisi arus dinamis seperti daerah yang mengarah ke laut lepas. Secara umum, hal ini sesuai dengan hasil yang diperoleh pada penelitian ini.

\subsection{Kandungan Karbon Organik Total pada Sedimen}

Konsentrasi kandungan karbon organik pada perairan muara Sungai Banyuasin memiliki kisaran 3,71\%-7,42\% (rata-rata

Table 1. The type of sediment substrate in the Banyuasin Estuary.

\begin{tabular}{ccccc}
\hline \multirow{2}{*}{ Station } & Sand & $\begin{array}{c}\text { Fraction (\%) } \\
\text { Silt }\end{array}$ & Clay & Substrate type \\
\hline 1 & 77.67 & 4.68 & 17.67 & Clayty sand \\
2 & 18.67 & 5.67 & 75.66 & Clay \\
3 & 20.75 & 12.57 & 66.68 & Sandy clay \\
4 & 89.78 & 4.77 & 5.45 & Silty sand \\
5 & 10.7 & 6.77 & 82.53 & Clay \\
6 & 74.87 & 20.78 & 4.35 & Silty sand \\
7 & 2.87 & 7.86 & 89.27 & Clay \\
8 & 2.76 & 9.76 & 87.48 & Clay \\
9 & 0.98 & 9.22 & 89.80 & Clay \\
10 & 36.88 & 7.84 & 70.96 & Sandy clay \\
\hline
\end{tabular}


$5,45 \pm 1,17 \%$ ). Grafik konsentrasi karbon organik total (Figure 2). Hasil pengukuran karbon organik total pada sedimen untuk masing-masing stasiun berturut-turut yaitu Stasiun 1 sebesar 4,24\%, Stasiun 2 sebesar $7,42 \%$, Stasiun 3 sebesar 5,83\%, Stasiun 4 yaitu 3,71\%, Stasiun 5 sebesar 6,36\%, Stasiun 6 sebesar 5,83\%, Stasiun 7 sebesar $4,77 \%$, Stasiun 8 sebesar 4,24\%, Stasiun 9 sebesar 6,36\%, dan Stasiun 10 sebesar 5,83\%. Stasiun 2 memiliki konsentrasi karbon organik tertinggi sebesar $7,42 \%$. Hal ini disebabkan karena lokasi stasiun 2 terletak dekat dengan dua muara sungai yaitu Sungai Banyuasin dan Sungai Lalan. Kedua muara ini berpotensi sebagai media pembawa limbah yang berasal dari daratan. Seitzinger et al. (2005) menyatakan bahwa sungai merupakan media pembawa bahan organik yang bersumber dari daratan menuju lautan melalui muara sungai. Selain itu, tingginya karbon organik total juga disebabkan karena pada stasiun 2 memiliki tipe substrat dominan lempung $(75,66 \%)$ sehingga kabron organik mudah mengendap dan terakumulasi.

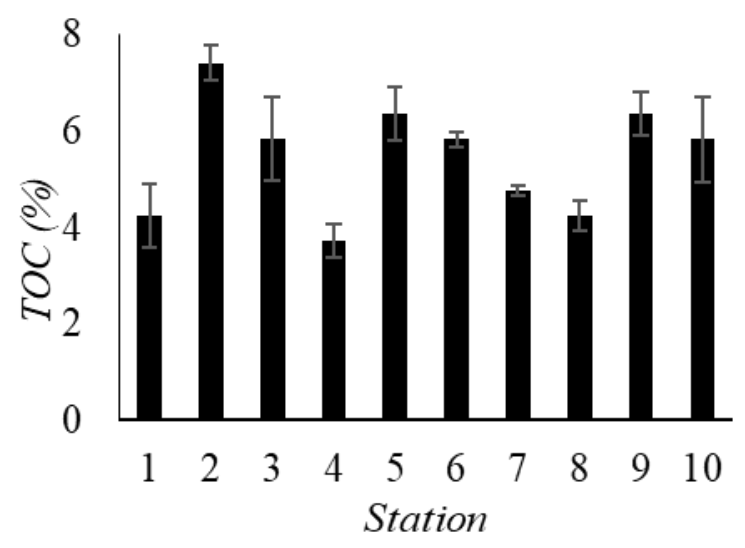

Figure 2. Composition of total organic carbon (TOC) (\%) at sediment observation sites in the Banyuasin Estuary.

Secara umum, kandungan bahan organik pada muara sungai bagian dalam lebih tinggi dibandingkan pada stasiun yang lebih mengarah ke laut. Karbon organik yang dibawa oleh aliran sungai akan terakumulasi di muara sungai sehingga menyebabkan kandungan karbon organik pada daerah muara sungai tersebut akan lebih tinggi dibandingkan wilayah yang terletak mengarah ke laut lepas (Blair \& Aller, 2012; Schlünz \& Schneider, 2000). Kandungan karbon organik kemudian mengendap di dasar perairan muara sungai dan terakumulasikan secara terus- menerus.

Stasiun 4 memiliki konsentrasi karbon organik terendah yaitu sebesar 3,71\% yang berbeda jauh pada stasiun stasiun yang lainnya. Rendahnya kandungan karbon organik total pada stasiun 4 karena memiliki substrat sedimen didominasi pasir $(89,78 \%)$ yang memiliki daya serap karbon organik total lebih rendah dibandingkan dengan sedimen dengan ukuran butir yang lebih halus. Hasil ini sesuai dengan penelitian Pratono et al. (2019) yang melaporkan substrat yang memiliki ukuran yang lebih besar/kasar menyerap karbon organik yang lebih sedikit dibandingkan dengan substrat yang lebih halus.

Nilai rata-rata karbon organik total yaitu $5,45 \%$ pada lokasi kajian menunjukkan nilai yang lebih tinggi dibandingkan muara sungai lain di Indonesia seperti Muara Sungai Citarum (Pratono et al., 2009). Hal ini dapat disebabkan oleh sedimen pada lokasi tersebut dominan bersubstrat lempung. Menurut Secrieru \& Oaie (2009) bahwa ukuran sedimen yang lebih halus akan memiliki ikatan yang kuat terhadap karbon organik total. Pada lokasi penelitian ini juga masih dipengaruhi oleh vegetasi mangrove dan tumbuh-tumbuhan di sekitarnya yang bisa menjadikan tingginya masukan bahan organik pada sedimen. Agussalim \& Hartoni (2014) melaporkan, kawaan mangrove di Muara Sungai Musi dan Banyuasin mencapai 2.424,327 ha. Madjid (2007) mengatakan bahwa sumber primer bahan organik tanah berasal dari jaringan organik tanaman yang dapat berupa daun, ranting dan cabang, batang, buah dan akar. Hasil pelapukan dari daun-daun yang berjatuhan dari tumbuhan 
serta organisme yang berasosiasi dengan tumbuhan yang kemudian mati dan terdegradasi dalam endapan sedimen akan menyebabkan keberadaan fosfor $(\mathrm{P})$ di dalam sedimen. Fosfat yang terdapat dalam air laut dapat berupa anorganik dan organik. Fosfor (P) di perairan dan sedimen berasal dari deposit fosfor $(\mathrm{P})$, industri, limbah domestik, aktivitas pertanian dan pertambangan batuan (Ruttenberg, 2003).

Menurut Pratono et al. (2009), konsentrasi karbon organik sedimen Perairan Muara Citarum berada pada kisaran antara 0,30\%-1,49\% dan dipengaruhi oleh tekstur sedimen. Karbon organik merupakan komponen penting dalam proses kimiawi sedimen.
Selain memiliki kemampuan menyerap materi kimiawi terlarut dalam kolom air, karbon organik juga memengaruhi sistem kimiawi seperti proses reduksi-oksidasi (redoks). Karbon organik akan teroksidasi dengan cara mengkonsumsi oksigen dalam proses dekomposisi. Jika karbon organik berlebih, oksigen terlarut dalam air akan habis dan menyebabkan kondisi anaerobik. Hal ini akan memberikan penhgaruh pada proses kimiawi yang terjadi dalam air dan sedimen (Pratono et al., 2009). Perbedaan nilai konsentrasi karbon organik total disebabkan oleh perbedaan sumber masukan bahan organik dan karbon organik total di setiap daerah.

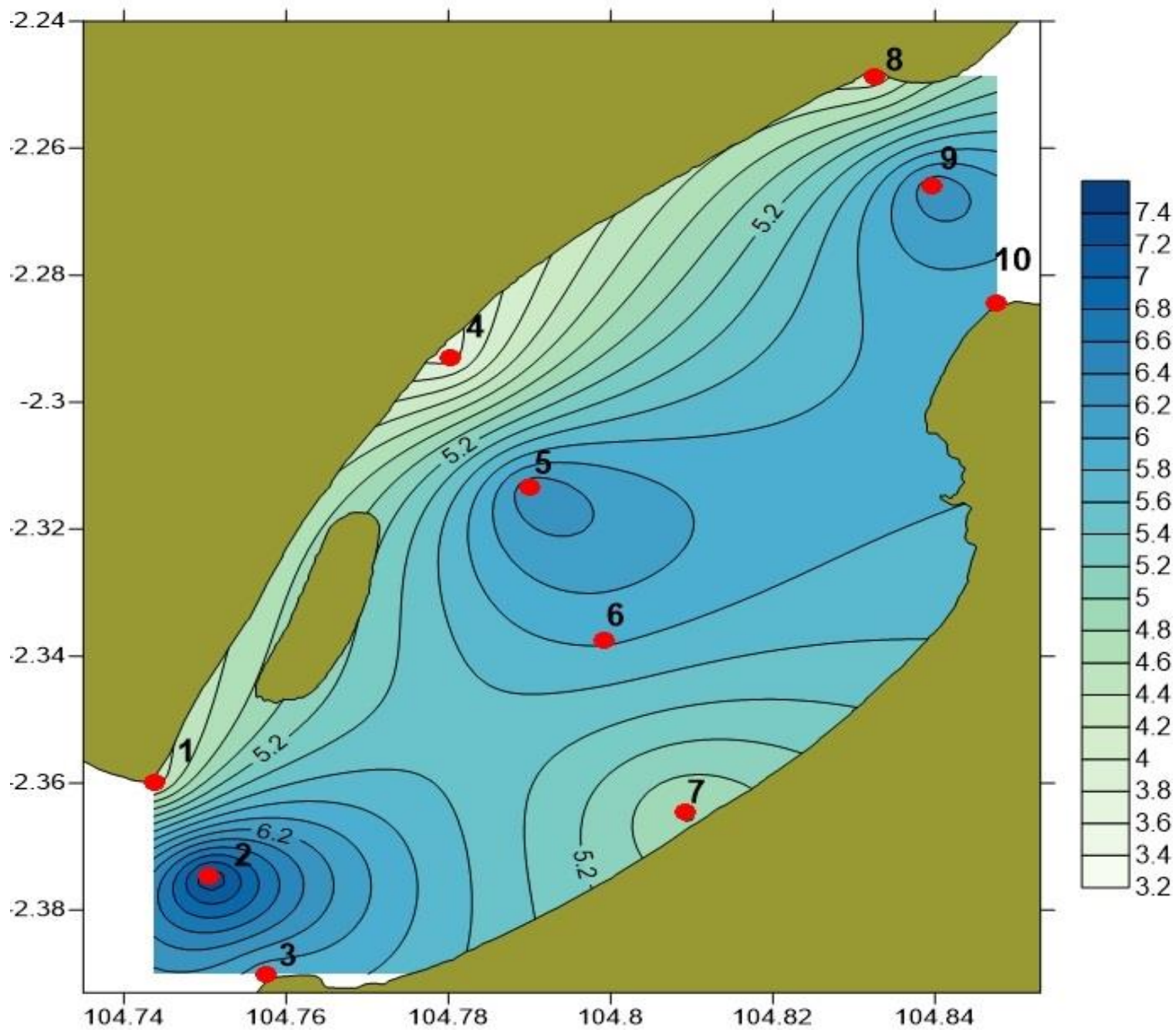

Figure 3. Distribution pattern of total organic carbon content in aquatic sediments in the Banyuasin Estuary. 


\subsection{Kandungan Fosfat pada Sedimen}

Fosfat merupakan bentuk lain dari fosfor (P) yang digunakan langsung oleh tumbuhan di air, sedangkan polifosfat harus diubah menjadi ortofosfat melalui hidrolisis sehingga dapat dimanfaatkan sebagai sumber fosfor (P) (McKelvie, 1999). Hasil analisis laboratorium menunjukkan bahwa kandungan fosfat di daerah penelitian berkisar $16,49 \mathrm{mg} / \mathrm{kg}-26,45 \mathrm{mg} / \mathrm{kg}$ (Figure 4). Kandungan fosfat tertinggi yaitu pada stasiun 5 dengan nilai konsentrasi sebesar 26,45 $\mathrm{mg} / \mathrm{kg}$ dan kandungan fosfat terendah yaitu terdapat pada stasiun 1 dengan nilai konsentrasi sebesar $16,459 \mathrm{mg} / \mathrm{kg}$. Rata-rata nilai kandungan fosfat pada sedimen perairan Muara Sungai Banyuasin adalah 22,06 $\pm 3,74$ $\mathrm{mg} / \mathrm{kg}$.

Manoarfa (1992) mengklasifikasi kandungan fosfat dengan kisaran nilai berikut: $<3 \mathrm{mg} / \mathrm{kg}=$ sangat rendah; 3-7 $\mathrm{mg} / \mathrm{kg}=$ rendah; $7-20=$ sedang; dan $>20$ $\mathrm{mg} / \mathrm{kg}=$ tinggi. Berdasarkan klasifikasi tersebut, maka stasiun $2,3,4,5,6,7,8,9$, dan 10 termasuk dalam kelompok tinggi, stasiun 1 berada dalam kategori konsentrasi fosfat yang sedang. Berdasarkan Hakanson \& Bryann (2008), perairan muara Sungai Banyuasin tergolong kedalam hypertrofik sehingga sangat mendukung bagi usaha perikanan.

Tingginya kandungan fosfat di daerah penelitian disebabkan oleh jenis substrat di daerah tersebut didominasi oleh lempung. Stasiun 5 memiliki nilai fosfat tertinggi dengan jenis substrat lempung. Substrat lempung memiliki ukuran partikel yang lebih halus sehingga memungkinkan untuk mengikat unsur-unsur yang terdapat di perairan. Aktivitas yang terdapat di sekitar sungai akan memberikan masukan berupa partikel organik yang akan mengendap di sedimen. Sedimen yang banyak mengikat bahan organik akan memiliki kandungan fosfat yang cukup tinggi pada daerah tersebut. (Dahuri et al., 1996). Tingginya kandungan fosfat pada daerah penelitian karena daerah tersebut merupakan daerah yang mengalami masukan limbah aktivitas manusia, limbah pabrik dan industri. Prianto et al. (2010) menyebutkan bahwa banyaknya aktivitas di sekitar sungai seperti pertanian, industri, perkebunan dan pemukiman menyebabkan masalah bagi kelestarian sumber daya perairan. Fosfat berasal dari berbagai masukan limbah dari daratan yang dibawa oleh arus dan diendapkan ke dasar perairan yang terdiri dari senyawa organik dan mineral anorganik (Santoso, 2007; Saraswati et al., 2017). Tingginya kandungan fosfat dapat dipengaruhi oleh difusi fosfat dari substrat. Paytan \& McLaughlin (2007) menyatakan bahwa sedimen berfungsi sebagai tempat penyimpanan fosfor $(\mathrm{P})$ terbesar di lautan.

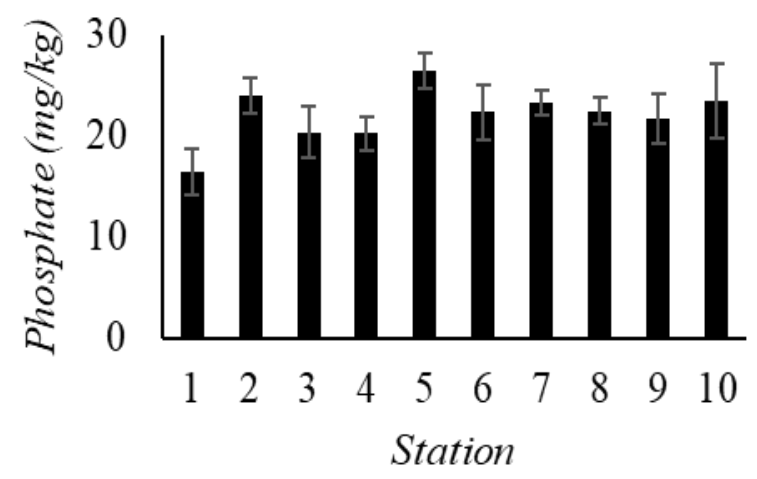

Figure 4. Phosphate concentration ( $\mathrm{mg} / \mathrm{kg}$ ) in sediments in the Banyuasin Estuary.

Stasiun 1 memiliki kandungan fosfat yang paling rendah, karena stasiun 1 merupakan titik pertemuan dua sungai yang menyebabkan tingginya kecepatan arus sehingga fosfat yang berasal dari aliran sungai menjadi sulit terendapkan. Selain itu, rendahnya kandungan fosfat pada stasiun ter-sebut juga dipengaruhi oleh substrat sedimen yaitu dominan substrat pasir. Pasir yang memiliki ukuran butir yang cenderung kasar tidak mempunyai daya serap yang tinggi terhadap bahan-bahan organik yang ada di perairan. Pola sebaran kandungan fosfat pada sedimen dapat dilihat pada Figure 5.

Kandungan fosfat pada sedimen di Muara Sungai Banyuasin memiliki pola seba- 


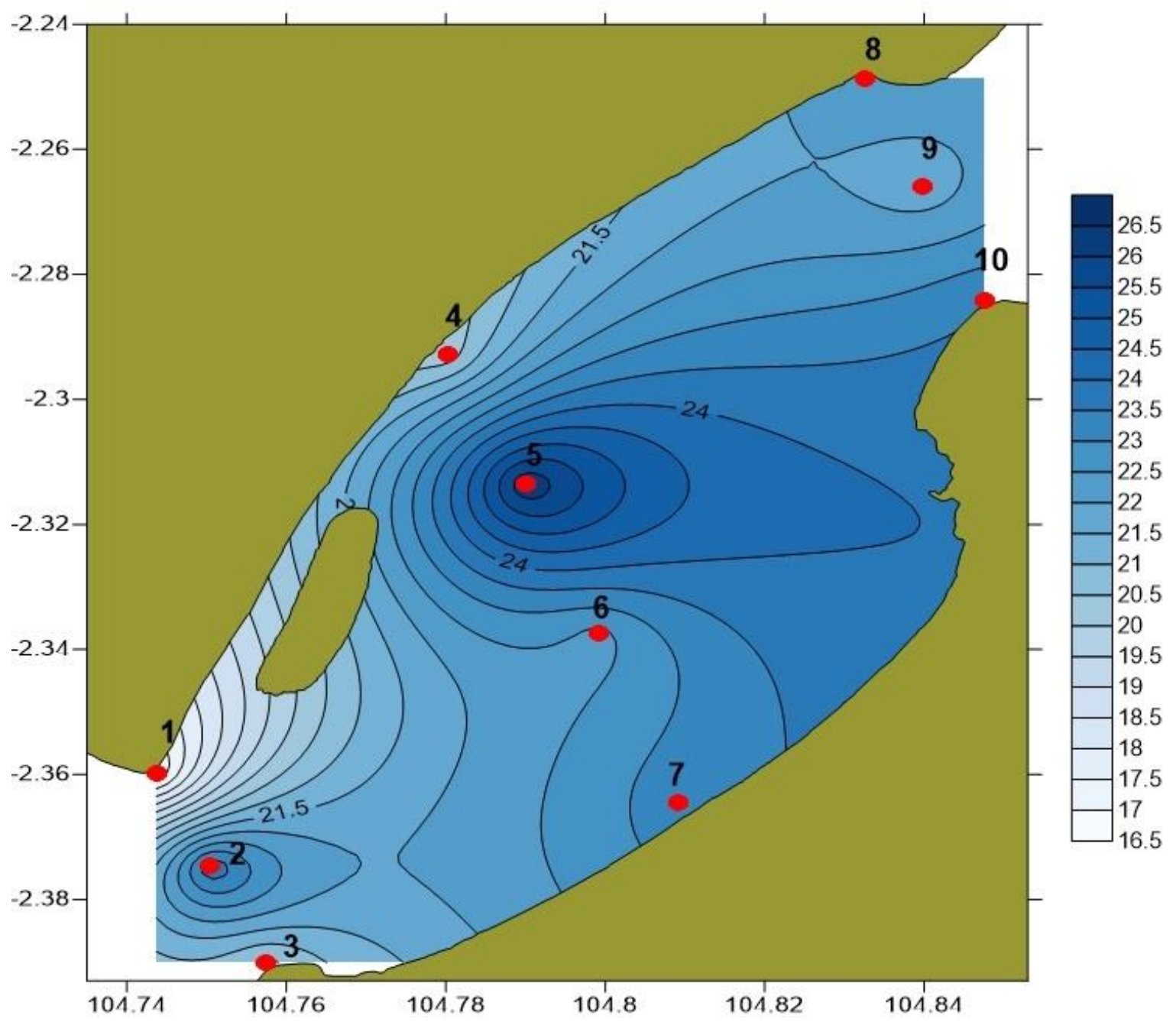

Figure 5. Distribution pattern of phosphate content in sediments in the Banyuasin Estuary.

ran bervariasi. Figure 5 menunjukkan bahwa stasiun 2, 5, 7 dan 10 merupakan daerah dengan konsentrasi fosfat yang tinggi. Tingginya fosfat pada stasiun tersebut diduga karena pengaruh masukan fosfat yang berasal dari Sungai Banyuasin hasil buangan limbah masyarakat dan terakumulasi dalam substrat. Selain itu juga dipengaruhi oleh tipe substrat yang terdapat pada stasiun tersebut adalah dominan lempung karena substrat lempung dan lumpur memiliki ukuran butiran yang lebih halus/kecil sehingga memiliki kemampuan menyerap dan mengakumulasi bahan organik yang lebih tinggi di-bandingkan tekstur yang kasar. Sedangkan Stasiun 1 dan 4 memiliki konsentrasi fosfat yang relatif lebih rendah dikarenakan tipe substrat pada stasiun tersebut dominan pasir. Stasiun 1 memiliki jenis substrat pasir berlempung dengan nilai persentase partikel pasir yang sangat tinggi yaitu $77,67 \%$. Fosfat organik juga merupakan fraksi yang melebihi setengah seluruh fosfat dalam tanah, hal ini menyebabkan kandungan fosfat begitu rendah dan sedikit adalah karena bentuknya yang kompleks dibandingkan unsur fosfor (P) (Paytan \& McLaughlin, 2007).

\subsection{Korelasi Kandungan Karbon Organik Total dan Fosfat}

Konsentrasi fosfat sedimen pada lokasi penelitian mempunyai korelasi yang positif dengan karbon organik total dengan nilai korelasi $r=0,567$, persamaan korelasi 
yaitu $P=1,2922 \mathrm{C}+15,015$. Korelasi positif ini mengartikan bahwa tingginya konsentrasi karbon organik total pada lokasi penelitian, maka akan diikuti dengan tingginya kandungan fosfat pada lokasi tersebut. Korelasi antara kandungan karbon organik total dan fosfat dapat dilihat pada Figure 6.

Beberapa penelitian juga menunjukkan korelasi positif antara kandungan karbon organik total dan kandungan fosfat di sedimen. Hutasoit (2014) melaporkan bahwa konsentrasi fosfat di perairan Sayung, Demak memiliki korelasi yang positif dengan karbon organik total dengan nilai koefisien $(r)$ sebesar 0,79. Penelitian Maulana et al. (2014) menyebutkan hasil korelasi konsentrasi fosfat dan karbon organik total di Perairan Muara Sungai Manyar dengan koefisien $(r)$ sebesar 0,89 . Konsentrasi fosfat di perairan dapat bersumber dari pelapukan batuan mineral dan dekomposisi bahan organik termasuk karbon dan juga dari aktivitas antropogenik di sekitar perairan seperti limbah pemukiman, pertanian, industri, dan lain-lain (Effendi, 2003) sehingga dapat dipahami bahwa semakin tinggi bahan organik disuatu perairan maka besar kemungkinan kandungan fosfat juga tinggi dan sebaliknya.

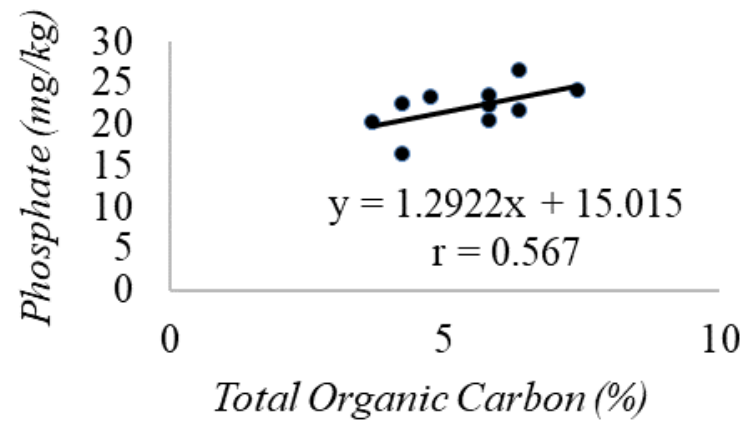

Figure 6. Correlation of total organic carbon and phosphate.

\section{KESIMPULAN}

Konsentrasi karbon organik total sedimen perairan muara Sungai Banyuasin mempunyai nilai rata-rata $5,45 \%$. Kandungan fosfat di perairan Muara Banyuasin dikategorikan sangat tinggi (hypertrofik) dengan nilai rata-rata $22,06 \mathrm{mg} / \mathrm{kg}$. Jenis substrat di perairan Muara Sungai Banyuasin sangat memengaruhi konsentrasi karbon organik total dan fosfat di perairan tersebut. Sedimen yang bertekstur halus mempunyai konsentrasi karbon organik total dan fosfat yang lebih tinggi di-bandingkan sedimen yang bertekstur kasar. Karbon organik total dan fosfat di perairan muara Sungai Banyuasin memiliki korelasi yang positif dan kuat yang menandakan bahwa semakin tinggi kandungan karbon organik total di perairan tersebut, maka semakin tinggi juga kandungan fosfat di perairan tersebut. Penelitian kedepannya disarankan untuk melakukan pengukuran parameter lain yang memiliki pengaruh terhadap konsentrasi karbon organik total dan fosfat seperti, arus, oksigen terlarut, dan lainlain sehingga dapat menjelaskan secara detail penyebab perbedaan konsentrasi karbon organik total dan fosfat di sedimen pada setiap stasiun.

\section{UCAPAN TERIMA KASIH}

Terima kasih kepada Fakultas Matematika dan Ilmu Pengetahuan Alam Universitas Sriwijaya yang telah memberikan Hibah Penelitian untuk pembiayaan penelitian ini, dan kepada semua pihak yang telah berkontribusi sehingga penelitian ini dapat dilaksanakan.

\section{DAFTAR PUSTAKA}

Agussalim, A. \& Hartoni. 2014. Potensi kesesuaian mangrove sebagai daerah ekowisata di Pesisir Muara Sungai Musi Banyuasin. J. Maspari, 6(2): 148-156.

https://doi.org/10.36706/maspari.v6i2 .3037

Allen, B.L. \& B.F. Hajek. 1976. Mineral occurrence in soil environments. In: J.B. Dixon and S.B. Weed (Editors), Minerals in Soil Environments 
(second edition). Soil Science Society of America, Madison, WI. 278 p.

Barus, B.S., R. Aryawati, W.A.E. Putri, E. Nurjuliasti, G. Diansyah, \& E. Sitorus. 2019. Hubungan N-total dan C-organik sedimen dengan makrozoobentos di perairan Pulau Payung, Banyuasin, Sumatera Selatan, J. Kelautan Tropis, 22(2): 147-156. https://doi.org/10.14710/jkt.v22i2.377 0

Blair, N.E. \& R.C. Aller. 2012. The fate of terrestrial organic carbon in the marine environment. Annual Review of Marine Science, 4: 401-423. https://doi.org/10.1146/annurevmarine-120709-142717

Bray R.H. \& L.T. Kurtz. 1945. Determination of total, organic and available forms of phosphorus in soils. Soil Science, 59:39-45. http://doi.org/10.1097/00010694194501000-00006

Dahuri, R., J. Rais, S.P. Ginting, \& M.J. Sitepu. 1996. Pengelolaan sumber daya. Jakarta: PT. Pramadya Pramita. Jakarta. $326 \mathrm{p}$.

Effendi, H. 2003. Telaah kualitas air bagi pengelolaan sumber daya dan lingkungan perairan. Penerbit Kanisius. Yogyakarta. 249 p.

François, R., S. Honjo, R. Krishfield, \& S. Manganini. 2002. Factors controlling the flux of organic carbon to the bathypelagic zone of the ocean. Global Biogeochemical Cycles, 16(4): 34-20. https://doi.org/10.1029/2001GB00172 2

Hakanson, L. \& A.C. Bryann. 2008. Eutrophication in the Baltic Sea present situation, nutrient transport processes, remedial strategies. Springer-Verlag. Berlin Heidelberg. $261 \mathrm{p}$.

Hartoni \& A. Agussalim. 2007. Laju sedimen tersuspensi di wilayah pembangunan pelabuhan Tanjung Api-Api muara Sungai Banyuasin Kabupaten Banyuasin. J. Penelitian Sains, 10(2): 204-211.

https://doi.org/10.36706/jps.v10i2.44 1

Hutasoit, R., S.S. Yulina, \& M. Yusuf. 2014. Studi kandungan karbon organik total (KOT) dan fosfat di Perairan Sayung, Kabupaten Demak. J. Oseanografi, 3(1): 74-80.

https://ejournal3.undip.ac.id/index.ph p/joce/article/view/4706

Latifah, I., P. Yanuar, \& H.P. Nora. 2013. Analisis kandungan karbon organik dalam sedimen di Sungai Jeneberang pada bagian hulu dengan mempergunakan model soil and water assesment tools. J. Teknik Hidraulik, 4(2): 117-128.

https://doi.org/10.32679/jth.v4i2.505

Madjid, A. 2007. Dasar-dasar ilmu tanah: Bahan ajar online. Fakultas Pertanian. Universitas Sriwijaya. Palembang, $275 \mathrm{p}$.

Manoarfa, W.D. 1992. Pemanfaatan limbah pabrik gula blotong dalam produksi klekap pada tanah tambak bertekstur liat. Program Pascasarjana. Universitas Hasanuddin. Makasar. 70 p.

Maulana, M., H.M. Lilik, \& Y.W. Sri. 2014. Studi kandungan fosfat bioavailable dan karbon organik total (KOT) pada sedimen dasar di muara Sungai Manyar Kabupaten Gresik. J. Osenaografi, 3(1): 32-36. https://doi.org/10.14710/buloma.v3i1. 11216

McKelvie, I.D. 1999. Phosphate. Handbook of water analysis. Marcel Dekker, Inc. New York. 273-295 pp.

Menon, R.G. 1973. Soil and Water Analysis. Food and Agriculture Organization. United Nations Development. New York. 188 p.

Muchtar, M. 2012. Distribusi zat hara, nitrat dan silikat di perairan Kepulauan 
Natuna. J. Ilmu Kelautan dan Teknologi Kelautan Tropis, 4(2): 304317.

https://doi.org/10.29244/jitkt.v4i2.779 2

Patty, S.I., H. Arfah, \& M.S. Abdul. 2015. Zat hara (fosfat, nitrat), oksigen terlarut dan $\mathrm{pH}$ kaitannya dengan kesuburan di Perairan Jikumerasa, Pulau Buru. J. Pesisir dan Laut Tropis, 1(1): 43-50. https://doi.org/10.35800/jplt.3.1.2015. 9578

Paytan, A. \& K. McLaughlin. 2007. Phosphorus in our waters. Oceanography, 20(2): 200-208. https://doi.org/10.5670/oceanog.2007. 71

Permatasari, I.R., B.S. Barus, \& G. Diansyah. 2019. Analisis nitrat dan fosfat pada sedimen di Muara Sungai Banyuasin, Kabupaten Banyuasin, Provinsi Sumatera Selatan. J. Penelitian Sains, 21(3): 140-150. https://doi.org/10.36706/jps.v21i3.54 5

Pratono, Razak, \& Gunawan. 2009. Pestisida organoklorine di sedimen pesisir Muara Citarum, Teluk Jakarta serta peran penting fraksi halus sedimen sebagai pentransport DDT dan proses diagenesanya. J. Ilmu dan Teknologi Kelautan Tropis, 1(2): 11-21. https://doi.org/10.29244/jitkt.v1i2.786 9

Prianto, E., Husnah, \& S. Aprianti. 2010. Karakteristik fisika kimia perairan dan struktur komunitas zooplankton di estuari Sungai Banyuasin, Sumatera Selatan. J. Bawal, 3(3): 149-157. http://doi.org/10.15578/bawal.3.3.201 0.149-157

Putri, W.A.E., A.I.S.Purwiyanto, Fauziyah, F. Agutriani, \& Y. Suteja. 2019. Kondisi nitrat, nitrit, amonia, fosfat dan BOD di muara Sungai Banyuasin, Sumatera Selatan. J. Ilmu dan Teknologi Kelautan Tropis, 11(1): 65-
74.

https://doi.org/10.29244/jitkt.v11i1.18 861

Rifardi. 2008. Tekstur sedimen sampling dan analisis. UNRI Press. Pekanbaru. 101 p.

Ruttenberg, K.C. 2003. The global phosphorus cycle. In: Treatise on Geochemistry. Elsevier. 643 p.

Santoso, A.D. 2007. Kandungan zat hara fosfat pada musim barat dan musim timur di Teluk Hurun Lampung. $J$. Teknik Lingkungan, 8(3): 207-210. http://doi.org/10.29122/jtl.v8i3.426

Sanusi, H.S. \& S. Putranto. 2009. Kimia laut dan pencemaran. Proses fisika kimia dan interaksinya dengan lingkungan. Departemen Ilmu dan Teknologi Kelautan, Fakultas Perikanan dan Ilmu Kelautan, Institut Pertanian Bogor. Bogor. 324 p.

Saraswati, N.L., I. Wayan, \& I.H. Gede. 2017. Analisis kualitas perairan pada wilayah perairan Pulau Serangan bagian utara berdasarkan baku mutu air laut. J. of Marine and Aquatic Science, 3(2): 163-170. https://doi.org/10.24843/jmas.2017.v3 .i02.163-170

Schlesinger, W.H. \& E.S. Bernhardt. 2013. Biogeochemistry: An analysis of global change. 3rd edition. Elsevier. $688 \mathrm{p}$.

Schlünz, B. \& R.R. Schneider. 2000. Transport of terrestrial organic carbon to the oceans by rivers: re-estimating flux- and burial rates. Int. J. Earth Science, 88: 599-606. https://doi.org/10.1007/s00531005029 0

Secrieru, D. \& G. Oaie. 2009. The Relation between the grain size composition of the sediments from the new black sea and their total organic carbon (TOC) content. Geo-Eco-Marina, 15: 5-11. https://doi.org/10.5281/zenodo.57303

Seitzinger, S.P., J.A. Harrison, E. Dumont, A.H.W. Beusen, \& A.F. Bouwman. 
2005. Sources and deliver of carbon, nitrogen, and phosphorous to the coastal zone: an overview of Global Nutrient Export from Watersheds (NEWS) models and their application. Global Biogeochemistry Cycles, 19: 478-492. https://doi.org/10.1029/2005GB00260 6

Simbolon, F., H. Surbakti, \& Hartoni. 2015. tersuspensi menggunakan teknik penginderaan jauh di perairan muara Sungai Banyuasin. J. Maspari, 7(2): $1-10$.

https://doi.org/10.36706/maspari.v7i2 .2432

Received : 21 January 2020

Reviewed : 4 May 2020

Accepted : 24 July 2020

Analisis pola sebaran sedimen 